\title{
Gender discrimination and its links with compensations and benefits practices in enterprises
}

\author{
Yuriy Bilan, Halyna Mishchuk, Natalia Samoliuk, Viktoriia Mishchuk
}

A B S T R A C T

Objective: The objective of the article is to determine links of gender discrimination with compensation and benefits practices, the main features of assurance of equal rights and their impact on employees' motives that can shift economic results of the enterprises.

Research Design \& Methods: For macro level analysis, we use graph and mapping method. Features of gender discrimination and its links with compensation and benefits are revealed in sociological review.

Findings: Ensuring gender equality is a difficult task for even the most developed countries of the world, as none of them has achieved full equality of sex, including in respect of labour rights. As our study shows, significant progress has been made in this area in Ukraine, as in general, gender gap and the economic equality of women keep within the EU-specific range of values. Gender discrimination is accompanied by age: $57.1 \%$ out of the $71.4 \%$ of discriminated women are aged under 35 ; the higher the age and gender discrimination, the smaller the wage gap. In enterprises with gender discrimination, the potential level of turnover is $71 \%$, which is significantly higher comparing to enterprises with equal rights.

Implications \& Recommendations: The obtained results should be used by trade unions and public policy makers in socio-labour agreements to reduce inequality in compensation and benefits practices.

Contribution \& Value Added: We suggest the developed approach to define gender discrimination in order to determine its features in compensation and benefits policy, but also to influence business results via assurance of equal rights of employees.

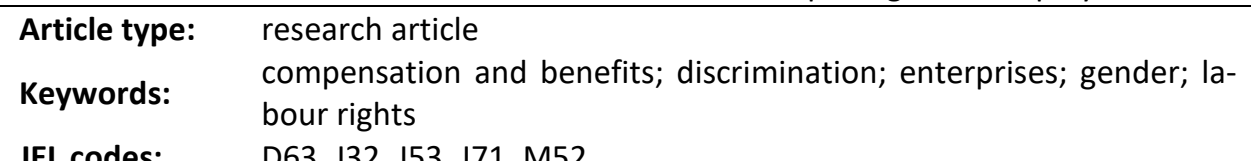

JEL codes: D63, J32, J53, J71, M52

Received: 11 May 2020

Revised: 16 June 2020

Accepted: 30 June 2020

\section{Suggested citation:}

Bilan, Y., Mishchuk, H., Samoliuk, N., \& Mishchuk, V. (2020). Gender discrimination and its links with compensations and benefits practices in enterprises. Entrepreneurial Business and Economics Review, 8(3), 189-204. https://doi.org/10.15678/EBER.2020.080311 


\section{INTRODUCTION}

Increasing inequalities - in particular income inequality and wealth or gender inequality are currently regarded as one of the major economic and social problems in the world (Kokocinska \& Puziak, 2018). Gender discrimination remains a significant problem for countries with both developed and immature economies. Gender inequality receives constant attention on the global level because its eradication is near to impossible. Thus, reducing gender inequality is the fifth of the seventeen Sustainable Development Goals, simultaneously very closely linked to Goal 8 of "Decent work and economic growth" (UNDP).

The importance of gender inequality issues requires constant attention from scientists and analysts. One of the studies showed that its macroeconomic impact can be very significant if sufficient progress is made in securing equal rights and related fields: education, more equal distribution of unpaid care work between women and men, improvement in labour market activity rates of women, increase in women's wages. Under these conditions, GDP per capita is projected to increase by nearly $10 \%$ by 2050 at the EU level, and there could be an additional 10.5 million jobs in the EU (70\% of which filled by women; EIGE, 2017, p. 53).

While trends and causes of gender inequality are constantly monitored at different levels, the economic impact of women's inequality in the workplace is rarely assessed. At the same time, experts from the International Labour Organization and PwC analysts found that GDP losses from gender inequalities in countries with different levels of development vary between $2.0 \%$ and $4.8 \%$ (ILO, 2017), and can even reach 10.8\% in OECD countries (PwC, 2017).

According to the most recent data published by the European Commission in the Gender Equality Strategy 2020-2024, today there is a $15.7 \%$ gender pay gap in the EU, while employment rate difference is $11.6 \%$ (European Commission, 2020).

In this regard, gender inequality and the factors behind its formation deserve constant attention and monitoring. One of the main areas in which such inequality manifests is the work. With significant differences in exercising the right to work, women suffer from inequalities not only at the stage of hiring and competing for jobs with men but also during the employment process. The well-known facts are inequalities in pay, career advancement, and work-life balance, especially given the unequal distribution of household responsibilities, which is also recognised to be one of the pressing problems at the EU level in the Gender Equality Strategy 2020-2024 (European Commission, 2020).

In such circumstances, gender economic inequality at the enterprise level could be smoothed out with an advanced system of social dialogue, compensation, and benefits practices. Although the issues of gender inequality - but also effective compensation and benefits planning - are well-known and well-researched, the study of their relationship makes it possible to obtain original scientific results. In particular, the novelty of our research is to develop a methodological toolkit for analysing the links between gender discrimination and the availability of compensation and rewards, along with the assessment of gender discrimination effects on companies in the form of redundancy motives.

Therefore, the objective of the article is to evaluate the current state of gender discrimination in enterprises in relation to the practice of compensation and benefits, and to analyse the links between gender discrimination and staff turnover (existing and potential release), which can have a significant impact on the results of economic activities. 
In order to achieve this goal, we address the following research questions: (1) to compare the general situation of gender discrimination in economic opportunities in Ukraine against the background of EU countries, taking into account the country's European integration intentions; (2) to evaluate the link between gender discrimination and other features of discrimination, including age; (3) to analyse the manifestations of discrimination in the availability of compensation and benefits in enterprises with different types regarding discrimination policies in order to identify the potential impact on the economic success of enterprises.

The article is organised as follows: the Literature Review section provides an overview of current scientific advances in gender discrimination, compensation, and benefits practices forms the basis of the research; the Methodology section describes hypotheses and appropriate tools for testing them; the main results of macro-level comparisons and our research into the manifestations and consequences of gender inequality in compensation and benefits practices are summarised in Results; the main research findings and possible directions for solving the problem, including in further research, are formulated in Conclusions.

\section{LITERATURE REVIEW}

One of the most useful techniques for monitoring gender equality is the methodology of the World Economic Forum, with annual studies of gender inequality. It claims that one of the main components of a significant gender gap is inequality in the direction of World Economic Forum WEF Economic 2020 Participation and Opportunity. At the macroeconomic level, this methodology (monitoring results or conceptual frameworks) is most often used to compare equity in respect of equality between men and women in various fields, including labour (Beham et al., 2019; Blackburn et al., 2016; Mishchuk et al., 2019).

The formation of inequalities in labor rights has the most pronounced features at the enterprise level, on which gender discrimination is still possible at the hiring stage. Very often, especially in transition economies, gender inequality is exacerbated by age, leading to the "widening [of] the gender gap in the employment structure to the benefit of older age groups" (Novikova \& Shamileva, 2020, p. 1; Šabić-Lipovača et al., 2016). In our study, we do not deny any age group the right to work; on the contrary, we proceed from the idea of guaranteeing the right to decent work and fair competition in the labour market for all population groups without any discrimination on the basis of sex, age, and similar.

At the same time, empirical studies in many countries prove that discrimination against women's labour rights is widespread today. It may be based on various factors, such as unequal educational opportunities (Dhar et al., 2018; He \& Wu, 2017; Klasen \& Minasyan, 2017), cultural norms and values (Davis \& Williamson, 2019), and discrimination on multiple grounds, such as educational attainment and marital status, as married women are much less likely to succeed than men (Gradín \& Tarp, 2019). Gender discrimination often depends on firms' characteristics, such as ownership, market orientation, and top manager's gender (Hoang \& Huynh, 2020) and its effects; besides inequality in employment, these elements also frequently impact the formation of pay (Plăiaș et al., 2011; Bilan et al., 2017; Espi et al., 2019).

As a result, violations of labour rights based on sex discrimination can significantly impede further motivation of women's professional development and - at the economic level of the country - hamper economic development and threaten women social wellbeing. Considering that EU countries have made much progress today in ensuring the 
equality of human rights and the country under scrutiny (Ukraine) seeks to integrate with the EU, the first hypothesis we intend to test in the study is:

H1: Gender discrimination in economic opportunities in Ukraine does not differ from the level acceptable in the EU, and there is progress in this direction thanks to the growing importance of European values.

Given that the foundations of inequality in economic opportunities are formed at the enterprise level, a deeper analysis of its causes and manifestations requires a study of the situation with inequality in the availability of economic incentives for employment.

Let us note that - besides the main incentive for employment in the form of remuneration whose inequality is a proven fact and does not require the collection of primary data - enterprises also use other motivation tools whose application can be accompanied with discrimination.

Such incentives, which determine the sense of justice and satisfaction with the job, are both compensation and benefits. It is difficult and inexpedient to fully list them, as they can significantly vary from country to country - what forms an added benefit for some is the norm for others - and be relevant to different types of businesses. For example, one study of job satisfaction in the academia (Mabaso \& Dlamini, 2017; Sułkowski et al., 2019) empirically demonstrated that the subjective assessment of job satisfaction was more dependent on compensation, but there appeared no significant effect between benefits and job satisfaction.

However, in order to choose between compensation and benefits, whose accessibility may be impeded by gender discrimination, we should identify the key components important to employees. Dependencies may differ for other activities. When compensation mainly comprises salary and traditional cash rewards (Fu \& Zhu, 2017; Maloa \& Bussin, 2016; Zeb et al., 2018), researchers in this topic focus on the fact that it is necessary today to place greater emphasis on nonpecuniary, tangible, and intangible rewards and recognition initiatives. In turn, such levers must be consistent with universal psychological needs (Thibault Landry et al., 2017). A common feature of all research in this field is understanding that total pay includes a fixed component or basic pay and other elements, such as benefits and performance bonuses or incentives, each of which can have a significant impact on staff motivation and performance. In some of them, compensation and benefits are not individually allocated and even vice versa, as benefits are included in compensation, understood as "all the extrinsic rewards that employees receive in exchange for their work," such as wages, bonuses, and benefits (Byars \& Rue, 2006, p. 249; Patiar \& Wang, 2020).

At the enterprise level, traditional components for empirical analysis of the availability of incentives for employment are the following components with greater or lesser detailing: mobility, training programs, other educational tools, sport reimbursement, benefits for employees' children, events, the ability to use corporate transportation, medical insurance, mobile communication payment, and corporate reputation (Akimov et al., 2020; Al-Tkhayneh et al., 2019; Jaworski et al., 2018; Knies et al., 2020; Stewart \& Brown, 2019; Babikova \& Bucek, 2019).

In the preparatory stage of our own research, we specified the components of compensation and benefits typical for human resources management in business, with owners of Ukrainian enterprises as prospective participants of the survey. Thus, our research summarised existing approaches to the analysis of components of compensation and benefits and 
identified those used in the practice of Ukrainian enterprises. On this basis, we aim to test the following hypothesis:

H2: Gender discrimination is manifested not only in wages but also in typical components of compensation and benefits for small and medium-sized businesses, such as providing employees with tuition fees, housing, food, transport costs, and granting soft loans.

In terms of analysing gender equality in the accessibility to compensation and benefits, it is important that other researchers argued that the conditions, under which benefits are strongly perceived as fair, are constraints on accessing and utilising benefits and the transparency of employee benefits (Laundon et al., 2019); whereas macroeconomic manifestations of injustice in the form of substantial differentiation of household incomes negatively impact macroeconomic indicators of well-being (Bilan et al., 2020).

The sense of fairness in the distribution of compensation and benefits created through participation in activities of an enterprise has a confirmed impact on organizational performance (Plăiaș et al., 2011; Al-Tkhayneh et al., 2019; Barrick et al., 2015; Chaikovska et al., 2017; Patiar \& Wang, 2020; Rasool et al., 2019; Turner, 2020).

Insufficient fairness in the accessibility to compensation and benefits is a prerequisite for reducing the economic performance of an organization in terms of job dissatisfaction and, consequently, employee turnover (Al Mamun \& Hasan, 2017; Blackburn et al., 2016; Stacho et al., 2019; Yu et al., 2019).

Due to dissatisfaction with working conditions, including compensation and benefits practices, we combine confirmed links of personnel layoffs with the importance of ensuring equal rights in their availability. So we put forward another hypothesis to be tested in our study:

H3: Gender discrimination significantly impacts the intentions of dismissing staff; these intentions are higher in enterprises that have not achieved gender equality.

\section{MATERIAL AND METHODS}

For $\mathrm{H} 1$ verification, we use the EU and Ukrainian statistics available from the WEF (2018, 2020). At the same time, to analyse the dynamics of gender equality - including the equality of economic opportunities - we use a graphical method that best illustrates the dynamics of gender gap index. We use the mapping tools of the Knoema Global Database (KNOEMA, 2019) to estimate changes in belonging to a particular group of countries by the differences in women's economic opportunities, but also changes in this index. MS Excel functions were used for relevant graph-analytical studies.

Hypotheses $\mathrm{H} 2$ and $\mathrm{H} 3$ were tested on the basis of data collected by us in the course of a sociological survey of representatives of small and medium-sized businesses in one of the regional centers of Ukraine.

The sample included 526 respondents, including 170 business owners and 356 employees. The survey was conducted from June to September 2018. Standard sampling error does not exceed $3.5 \%$ for small and medium-sized enterprises owners and $2.6 \%$ for employees, with a $95.4 \%$ confidence level. 
Manifestations of gender discrimination are identified by the general subjective assessment of its existence in enterprises - according to employee estimates - but also in the assessments of inequality of access to the components of compensation and benefits identified earlier in the Literature Review.

The study of gender discrimination impact on the formation of motives for dismissal, according to employees, was conducted in groups of enterprises formed for the following characteristics: enterprises with gender and age discrimination; enterprises with no discrimination. Age discrimination was further explored in the light of respondents' assessment that it often complements gender discrimination.

The data processed by graph-analytical method allowed us to identify main features of gender discrimination, analyse the links between discrimination and the availability of individual components of compensation and benefits, but also the differentiation of wages according to gender and age equality in enterprises.

\section{RESULTS AND DISCUSSION}

To test the H1 hypothesis, we use the Global Gender Gap Index, which assesses gender gaps in terms of health and longevity, educational attainment, political rights and opportunities, career growth, and economic life.

At present, no country overcame gender inequality. In 2019, the global gender gap is at $68.6 \%$, which means that there is still $31.4 \%$ needed to achieve the full equality of women and men. However, there are five countries that show a gender gap of less than 20\%: Iceland, Norway, Finland, Sweden, and Nicaragua. Three more EU countries - Ireland, Spain, Germany - rank among the ten countries with the smallest gender gap. At the same time, Ukraine ranks 59th out of 153 countries, improving its position compared to the previous year by six points, and increasing the gender parity indicator from 0.708 to 0.721 (Figure 1). Hence, to achieve $100 \%$ gender equality, Ukraine lacks $27.9 \%$, while the world leader (Iceland) $-12.3 \%$ and the EU leader (Finland) $-16.8 \%$.

Thus, the above partially confirms our hypothesis that gender equality in Ukraine - at least according to monitoring data - shows a level close to European values. No one value about Ukraine is worse when compared to those obtained in European countries.

However, the dimension in which the gender gap globally has the largest spread is the one measured by the Economic Participation and Opportunity subindex. Here, only $58 \%$ of the gap has been closed so far, and it slightly widened since last year. The dispersion between the best performing countries and those at the bottom of the ranking is substantial. While the top 10 countries have closed at least $80 \%$ of the gap, the bottom 10 countries have only closed $40 \%$ of the gap between men and women in the workplace (WEF, 2020, p.10).

In 2018, among the 10 best performers in this subindex, there appeared only two from the EU: Sweden and Latvia, and in 2019 only Latvia (Figure 2). The largest gender gap for Economic Participation and Opportunity subindex among EU countries is observed in Italy, although it diminished by $0.3 \%$ in one year. In Ukraine the gender gap is much smaller than the Global Gender Gap Index overall, and the 2018 ranking is much better than in Italy: 28th place against 118th. However, the dynamics in Ukraine is followed by a negative trend: in one year the gap increased by $1 \%$ and the country lost 11 points in the rating. 


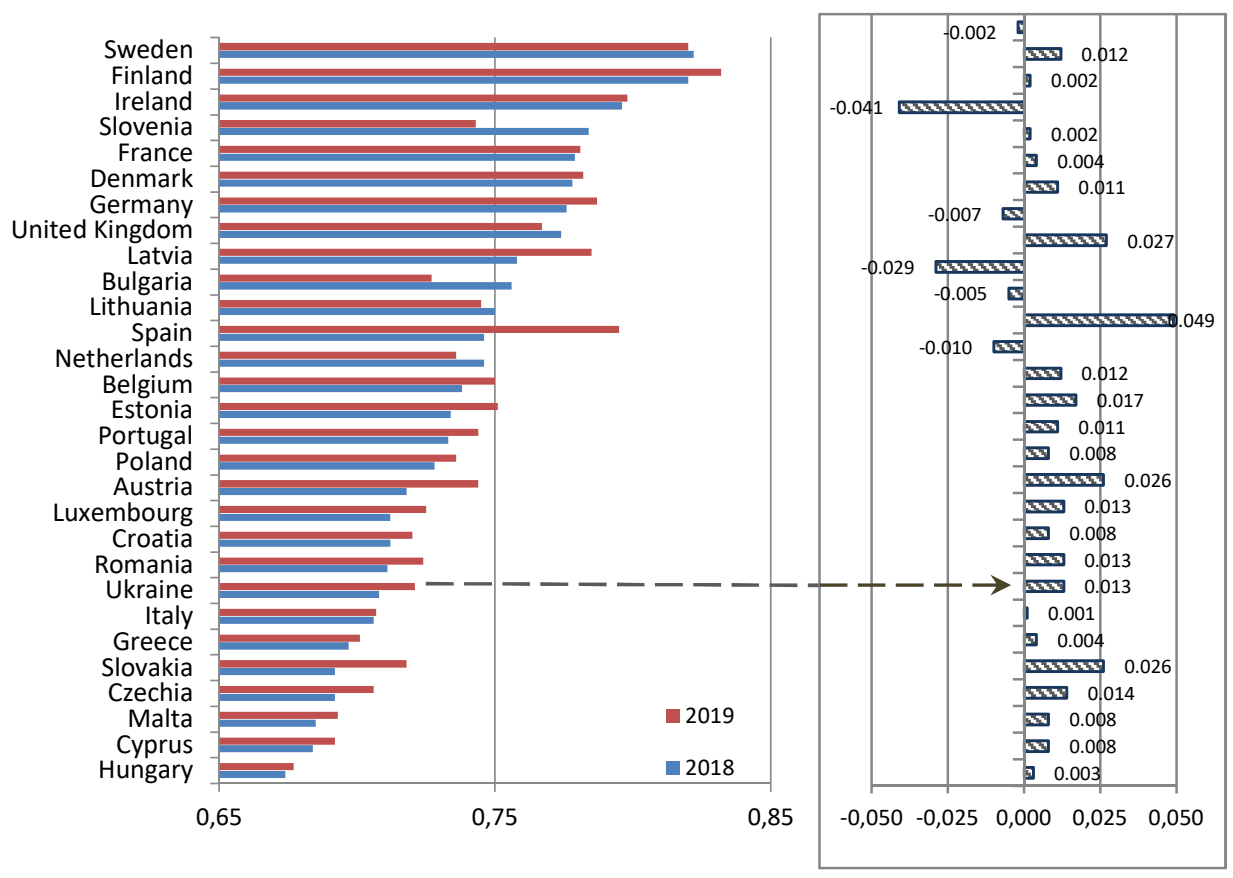

Figure 1. Global Gender Gap Index, 2018-2019 (including changes of index value in 2019 compare to 2018)

Source: own elaboration based on WEF $(2018,2020)$.

Thus, the above comparisons reveal that gender discrimination in Ukraine - which shares European values and has repeatedly confirmed its European integration intentions - lies within the EU's typical borders. At the same time, Ukraine has significant reserves compared to EU leaders in minimising the gender gap, including equal economic opportunities of women.

EU leaders' identification and involvement in combating discrimination is as an important area not only at the level of the state monitoring of human rights respect. More and more companies use gender equality assessments in their own corporate policies. For example, one of the world-wide examples of micro-level gender equality assessments is the Bloomberg Gender Equality Index. In particular, in 2019 this index was calculated according to the data of 230 international companies. $60 \%$ of these companies conduct regular internal reviews on gender-based pay issues; $91 \%$ of companies that identified any wage gap made efforts to correct this injustice (Bloomberg, 2019). Hence, the results of these reviews are used to make adjustments to corporate policies so as to achieve gender equality.

As for Ukraine, in 2019, the Ukrainian Marketing Group conducted an online survey of Ukrainian companies' staff (1000 respondents) to identify the most pressing gender issues that Ukrainian private sector employees may face. The survey found that $70 \%$ of the interviewees did not have any prejudice against their professional colleagues because of their gender. Among those who mentioned such cases, they were most often confronted with lower wages (10\%), doubts about professional skills $(10 \%)$, rejections 
of applications for employment (8\%), and offensive and unacceptable statements and sexual jokes (8\%). Career denials, reluctance to give serious/important assignments, psychological pressure, and even unacceptable sexual acts were also reported (UNFPA Ukraine, 2019). As we can see, such results generally confirm the previously revealed level of gender discrimination in economic opportunities: estimates of gender inequality actually coincide with those shown in Figure 2 .

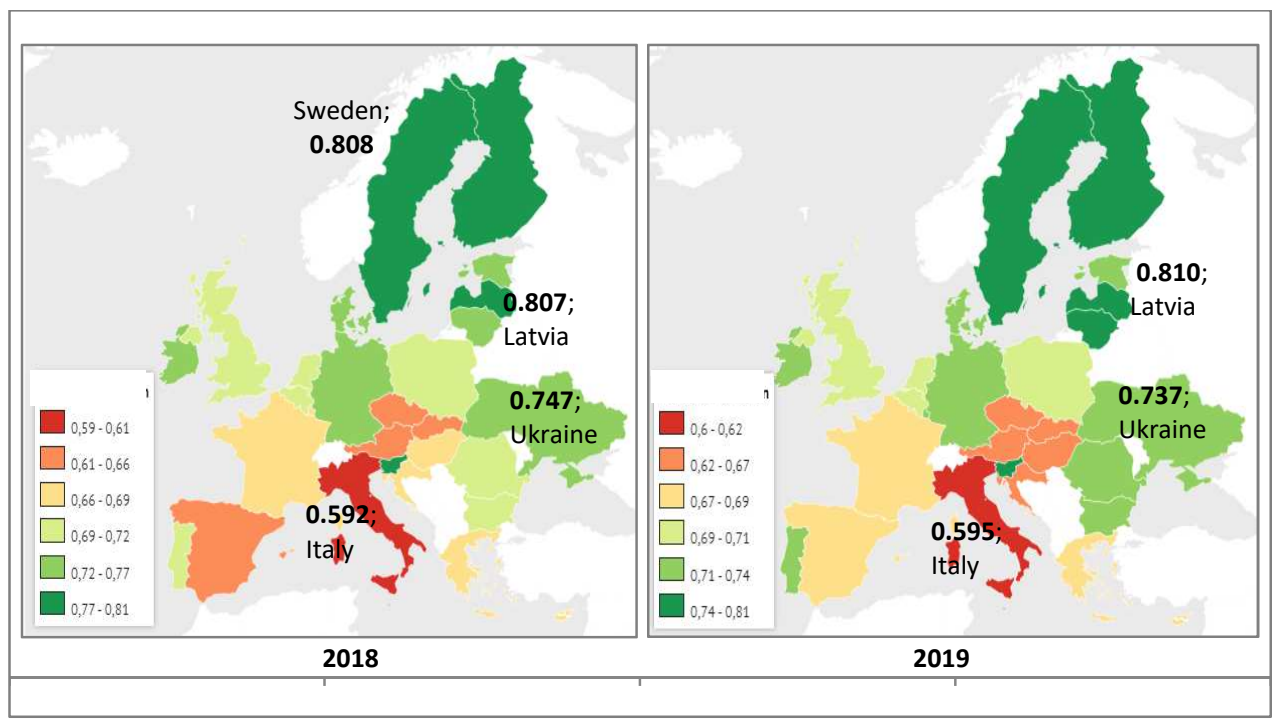

Figure 2. Economic Participation and Opportunity index, 2018-2019

Source: own elaboration based on WEF $(2018 ; 2020)$ and KNOEMA (2019).

The $\mathrm{H} 2$ hypothesis was tested using the data from own survey of owners and employees of small and medium-sized enterprises in Ukraine. The structure of respondents was as follows: $64 \%$ women, $36 \%$ men; $54 \%$ under 35 -years-old, $37 \% 35-50$-years-old; $51 \%$ of workers, $42 \%$ professionals/employees, and only $7 \%$ managers.

The survey revealed that gender discrimination is most often accompanied by age discrimination. $15 \%$ of respondents said that they faced discrimination on the basis of gender and age in their work activities. At the same time, women most often face gender discrimination under the age of $35(57 \%)$ when working in specialist positions at enterprises with 50-250 employees. At the same time, manifestations of age discrimination were revealed mainly by workers and specialists under the age of $35(65.9 \%)$ who work at enterprises employing 11-50 people. A detailed breakdown of respondents by discrimination is given in Table 1 .

An analysis of respondents' answers showed that the discrimination they faced was reflected in the level of wages (34\%), career opportunities (27\%), and working conditions, including working hours (29\%). Noteworthy, the issue of gender differentiation in wages is also relevant for EU countries, where the wage gap between women and men averages 16.1\% (Eurostat, 2019). However, our survey showed that the capacities for employees of small and medium-sized enterprises in Ukraine are much higher. 
Table 1. Discrimination within different categories of staff in small and medium-sized enterprises

\begin{tabular}{|c|c|c|c|c|c|c|c|c|c|c|c|c|}
\hline \multirow{2}{*}{$\begin{array}{l}\text { Type of } \\
\text { discrim- } \\
\text { ination }\end{array}$} & \multirow{2}{*}{ Sex } & \multirow[t]{2}{*}{$\%$} & \multicolumn{3}{|c|}{ Age (in \%) } & \multicolumn{3}{|c|}{ Staff category (in \%) } & \multicolumn{4}{|c|}{$\begin{array}{l}\text { Number of employees } \\
\text { (in \%) }\end{array}$} \\
\hline & & & $<35$ & $35-50$ & $>50$ & worker & specialist & manager & $<5$ & $6-10$ & $11-50$ & $51-250$ \\
\hline \multirow{3}{*}{ Gender } & women & 71.4 & 57.1 & 7.1 & 7.1 & 28.6 & 35.7 & 7.1 & 7.1 & 7.1 & 14.3 & 42.9 \\
\hline & men & 28.6 & 28.6 & 0.0 & 0.0 & 21.4 & 0.0 & 7.1 & 0.0 & 7.1 & 14.3 & 7.1 \\
\hline & all & 100.0 & 85.7 & 7.1 & 7.1 & 50.0 & 35.7 & 14.3 & 7.1 & 14.3 & 28.6 & 50.0 \\
\hline \multirow{3}{*}{ Age } & women & 56.1 & 39.0 & 14.6 & 2.4 & 29.3 & 22.0 & 4.9 & 9.8 & 9.8 & 22.0 & 12.2 \\
\hline & men & 43.9 & 26.8 & 17.1 & 0.0 & 24.4 & 12.2 & 7.3 & 0.0 & 12.2 & 22.0 & 9.8 \\
\hline & all & 100.0 & 65.9 & 31.7 & 2.4 & 53.7 & 34.1 & 12.2 & 9.8 & 22.0 & 43.9 & 22.0 \\
\hline \multirow{3}{*}{$\begin{array}{l}\text { No dis- } \\
\text { crimina- } \\
\text { tion }\end{array}$} & women & 64.7 & 38.3 & 20.0 & 6.4 & 31.5 & 29.5 & 3.7 & 20.7 & 9.2 & 15.9 & 18.0 \\
\hline & men & 35.3 & 15.3 & 17.3 & \begin{tabular}{|l|}
2.7 \\
\end{tabular} & 20.0 & 12.2 & 3.1 & 3.7 & \begin{tabular}{|l|}
8.8 \\
\end{tabular} & 8.1 & 14.2 \\
\hline & all & 100.0 & 53.6 & \begin{tabular}{|l|}
37.3 \\
\end{tabular} & 9.2 & 51.5 & 41.7 & 6.8 & 24.4 & 18.0 & 24.1 & 32.2 \\
\hline
\end{tabular}

Source: own study.

In the course of the study, we also found links between discrimination and wage differentiation in enterprises: the higher the age and gender discrimination, the smaller the wage gap (Figure 3). This indicates that in enterprises with gender and age discrimination the chances for employees to assume higher-level positions with higher wages are much lower than in non-discrimination enterprises. Successful businesses with lower levels of age and gender discrimination experience a much larger wage gap, but this is offset by the real ability of each employee to have a successful career, accompanied by higher wages.

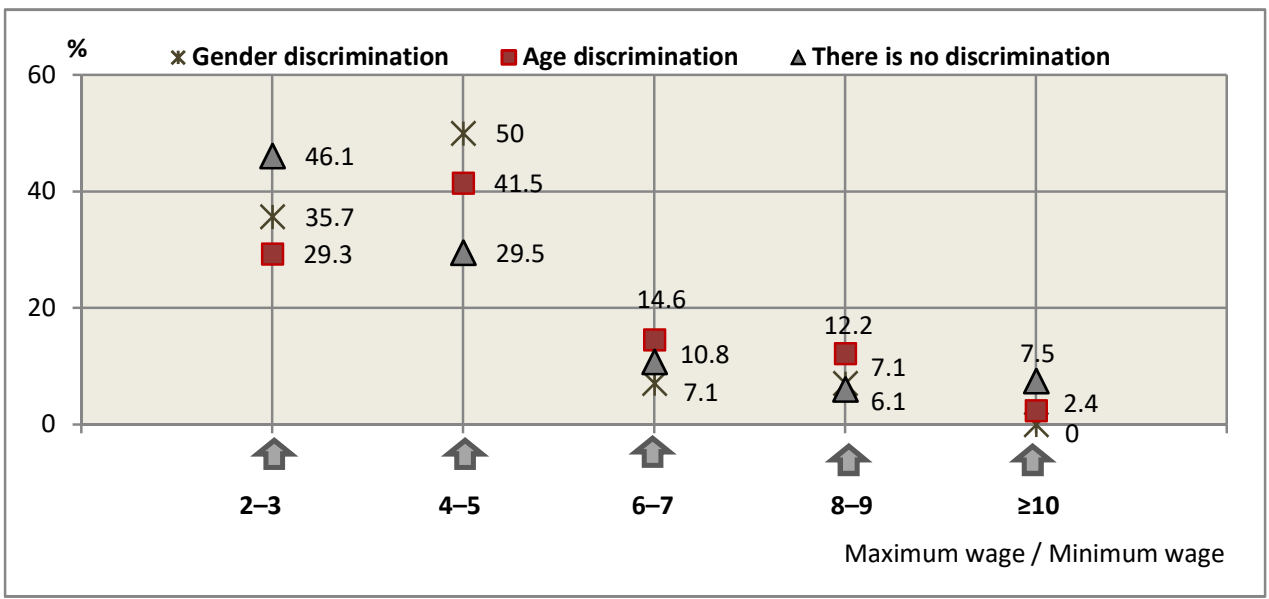

Figure 3. The allocation of employees by differentiation of wages in enterprises with different discrimination policies Source: own elaboration.

However, given that wages are only one of the components of enterprise compensation policy, we examined gender discrimination and other components of compensation and benefits typical of HR practices in Ukrainian businesses. 
The results of the study indicated that compensation and benefits are generally distributed in enterprises where there is no discrimination. This is most relevant for such components as "providing full meals" and "paying for long-term tuition" (Figure 4). At the same time, other compensations and benefits are present in all enterprises, although they are most prevalent where there is no discrimination.

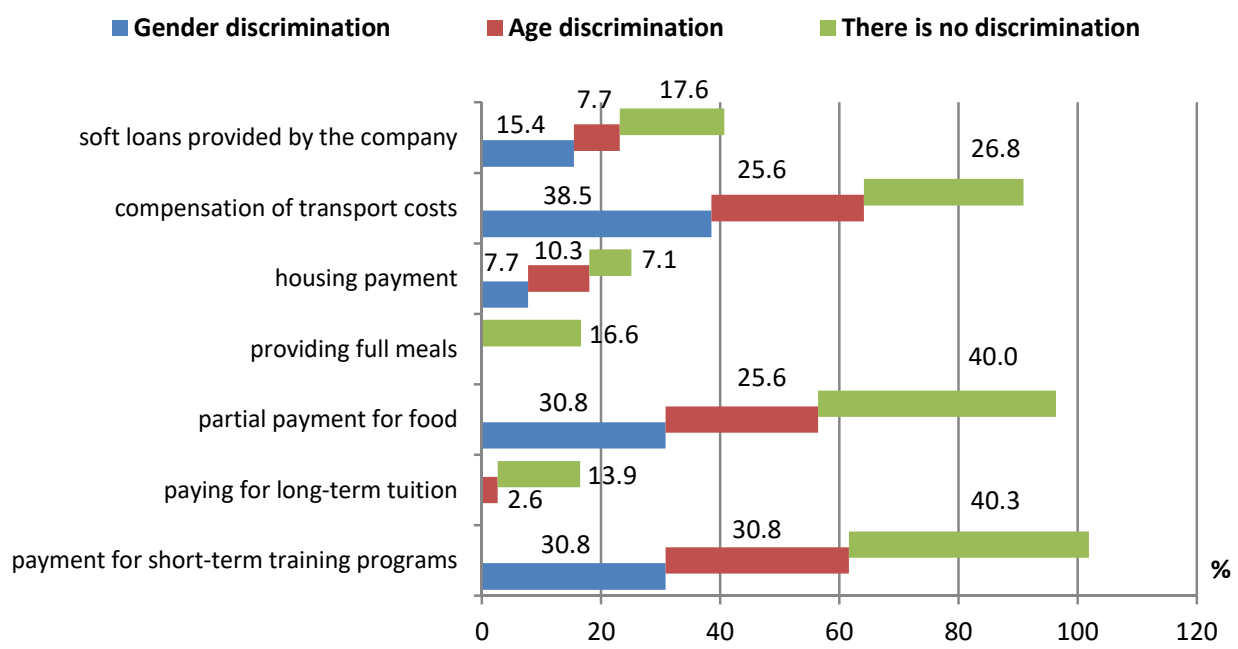

Figure 4. The availability of components of compensation and benefits in enterprises with different discrimination policies

Source: own elaboration.

Therefore, testing the $\mathrm{H} 2$ hypothesis allowed us to confirm the assumption that, in companies with gender equality, the components of compensation policy are more accessible and include both compensation and additional benefits for employees. On the other hand, according to a number of compensation payments (compensation for transport costs, payment for meals and short-term training programs), the estimates of the availability of such programs are either close to those expressed in enterprises with no discrimination, or even higher (transport costs). Such results, together with the manifestations of discrimination against women at these enterprises, are attributed to the fact that these compensations are more accessible to men.

As part of the test of $\mathrm{H} 3$ hypothesis, we can confirm that insufficient protection of equality of rights at enterprises becomes the basis for the formation of negative motives for employees. Thus, in enterprises with gender discrimination, the potential level of turnover is $71 \%$, which is twice as much as the analogous indicator of enterprises with equal rights (29\%), as well as enterprises with age discrimination (39\%).

Thus, even with the possible subjective exaggeration of dissatisfaction in respondents' estimates, the risk of significant economic losses to employers as a result of redundancies due to violation of labour rights is obvious. At the same time, as shown in Table 2, business owners are not even aware of the depth of the problem, including the impact that discrimination may have on the stability of their activity and economic success. 
Therefore, enterprises face the need to modify their personnel policies, taking into account measures to ensure gender equality.

Table 2. Current and potential indicators of staff turnover in enterprises with different discrimination policies

\begin{tabular}{|l|c|c|}
\hline $\begin{array}{c}\text { Presence of discrimination } \\
\text { in enterprises }\end{array}$ & $\begin{array}{c}\text { Actual staff turnover, \% (esti- } \\
\text { mate of business owner) }\end{array}$ & $\begin{array}{c}\text { Potential staff turnover, \% } \\
\text { (estimate of employees) }\end{array}$ \\
\hline Gender discrimination & 35 & 71 \\
\hline Age discrimination & 27 & 39 \\
\hline There is no discrimination & 25 & 29 \\
\hline
\end{tabular}

Source: own study.

\section{CONCLUSIONS}

Ensuring gender equality is a difficult task for even the most developed countries of the world, as none of them has achieved full equality of sex, including in respect of labour rights. As our study shows, significant progress has been made in this area in Ukraine, as in general, gender gap and the economic equality of women keep within the EUspecific range of values.

However, by examining two other hypotheses at the level of small and medium-sized enterprises in which labour rights violations are less monitored, we find that discrimination against women is still high enough in such enterprises, comprising at least $15 \%$, which mostly agrees with the WEF Global Report for Ukraine. Nevertheless, in some age groups the discrimination situation is very tense: mostly for young women under the age of 35 , who do not belong to a managerial level.

The most important manifestations of discrimination are inequality in pay, working hours, and career advancement. In terms of the availability of compensation and benefits, it is higher in non-gender-sensitive enterprises, as expected. Instead, in companies with explicit gender discrimination, men are more likely to benefit from compensation such as transportation costs, meals, and short-term training programs. Combining this with the previously identified signs of discrimination against non-managerial female workers and professionals, we can establish interdependence of gender discrimination and the use of job opportunities. In such a way, managerial employees are provided with greater accessibility to compensation and benefits packages.

By testing the hypothesis of a link between gender discrimination and potential fluidity, we confirm that the insufficient assurance of equal rights in enterprises becomes the basis for the formation of negative employee motivation. Thus, dissatisfaction with the existing level of gender rights emerges from the fact that in enterprises characterised by discrimination, the potential staff turnover surpasses $70 \%$ and in fact exceeds twice the same indicator for enterprises with no discrimination. Such results threaten not only social but also economic losses for businesses. Indeed, as one international study found, the implementation of the principle of gender equality and non-discrimination leads to increased productivity and efficiency of organizational and managerial processes, hence the profitability of companies. For example, a report by Diversity Matters (McKinsey, 2015) found that gender diversity companies are $15 \%$ more likely to have financial returns above their respective national industry medians. 
Thus, gender issues and gender non-discrimination standards should attract the attention of Ukrainian companies, as compliance with relevant development norms and priorities can deliver tangible economic results. Gender benchmarks for socially responsible companies are defined by a number of different international and national commitments that Ukraine has undertaken. At the same time, we clearly see the need for the development of social responsibility of business owners, along with the activation of trade union movement. First and foremost, the development of social dialogue must concern the consolidation of equal treatment norms in the work process, the formulation of compensation and benefits policies, and the definition of non-discriminatory principles for their implementation. Enshrined in the form of social and employment agreements at various levels, such arrangements will allow these elements to be used as a tool for monitoring and regulating stakeholder relations.

At the same time, the scientific and practical principles of social dialogue development, the search and implementation of effective mechanisms for its activation in Ukraine, and most importantly, compliance with the commitments, count among the topics for future scientific research.

\section{REFERENCES}

Akimov, O., Karpa, M., Parkhomenko-Kutsevil, O., Kupriichuk, V., \& Omarov, A. (2020). Entrepreneurship education of the formation of the e-commerce managers professional qualities. Journal of Entrepreneurship Education, 23(S1).

Al Mamun, C.A., \& Hasan, M.N. (2017). Factors affecting employee turnover and sound retention strategies in business organization: a conceptual view. Problems and Perspectives in Management, 15(1), 63-71.

Al-Tkhayneh, K., Kot, S., \& Shestak, V. (2019). Motivation and demotivation factors affecting productivity in public sector. Administratie si Management Public, 33, 77-102.

Babikova, K., \& Bucek, J. (2019). A Model Replication with an Extension of Students' Perception of Prospective Employer Attractiveness. Journal of Competitiveness, 11(2), 5-21.

Barrick, M.R., Thurgood, G.R., Smith, T.A., \& Courtright, S.H. (2015). Collective organizational engagement: Linking motivational antecedents, strategic implementation, and firm performance. Academy of Management Journal, 58(1), 111-135.

Beham, B., Drobnič, S., Präg, P., Baierl, A., \& Eckner, J. (2019). Part-time work and gender inequality in Europe: a comparative analysis of satisfaction with work-life balance. European Societies, 21(3), 378-402.

Bilan, Y., Mishchuk, H., \& Dzhyhar, T. (2017). Human capital factors and remuneration: analysis of relations, modelling of influence. Business: Theory and Practice, 18, 208-214. https://doi.org/10.3846/btp.2017.022

Bilan, Y., Mishchuk, H., Samoliuk, N., \& Yurchyk, H. (2020). Impact of Income Distribution on Social and Economic Well-Being of the State. Sustainability, 12(1), 429. https://doi.org/10.3390/su12010429

Blackburn, R.M., Jarman, J., \& Racko, G. (2016). Understanding gender inequality in employment and retirement. Contemporary Social Science, 11(2-3), 238-252.

Bloomberg (2019). Bloomberg Gender-Equality Index Doubles in Size, Recognizing 230 Companies Committed to Advancing Women in the Workplace. Retrieved from https://www. blooberg.com/company/press/2019-bloomberg-gender-equality-index/ on May 2, 2020. 
Byars, L.L., \& Rue, L.W. (2006). Human resource management (8th ed.). Boston: McGrawHill Irwin.

Chaikovska, I., Fasolko, T., Vaganova, L., \& Barabash, O. (2017). Economic-mathematical tools for building up a project team in the system of company's knowledge management. Eastern-European Journal of Enterprise Technologies, 3(3-87), 29-37. https://doi.org/10.15587/17294061.2017.103185

Davis, L.S., \& Williamson, C.R. (2019). Does individualism promote gender equality? World Development, 123, 104627.

Dhar, R., Prakash, V., \& Singh, B. (2018). Gender Inequality: A Comparison of India and USA. In Reflecting on India's Development (pp. 251-269). Singapore: Springer.

EIGE. (European Institute for Gender Equality). 2017. Economic Benefits of Gender Equality in the European Union (Report on the Empirical Application of the Model). Luxembourg: Publications Office of the European Union, 152.

Espi, G., Francis, D., \& Valodia, I. (2019). Gender inequality in the South African labour market: Insights from the Employment Equity Act data. Agenda, 1-18.

European Commission (2020). A Union of Equality: Gender Equality Strategy 2020-2025. Brussels, 5.3.2020.

Eurostat (2019). Statistics Explained, Employment statistics. Retrieved from https://ec.europa.eu/eurostat/ on May 3, 2020.

Fu, R., \& Zhu, M. (2017). Study on the Human Resource Management System in Innovative Enterprises (2nd International Conference on Politics, Economics and Law (ICPEL 2017). Atlantis Press.

Gradín, C., \& Tarp, F. (2019). Gender inequality in employment in Mozambique. South African Journal of Economics, 87(2), 180-199.

He, G., \& Wu, X. (2017). Marketization, occupational segregation, and gender earnings inequality in urban China. Social Science Research, 65, 96-111.

Hoang, H.T., \& Huynh, L.T. (2020). Impact of Firm's Characteristics on Gender Discrimination: Evidence from Vietnamese Firm-level Data. Montenegrin Journal of Economics, 16(1), 21-35.

ILO (2017). International Labour Organization: Economic impacts of reducing the gender gap. Research Brief $N^{\circ} 10$. Retrieved from http://www.ilo.org/wcmsp5/groups/public/---dgreports/--inst/documents/publication/wcms_577685.pdf on April 26, 2020.

Jaworski, C., Ravichandran, S., Karpinski, A.C., \& Singh, S. (2018). The effects of training satisfaction, employee benefits, and incentives on part-time employees' commitment. International Journal of Hospitality Management, 74, 1-12.

Klasen, S., \& Minasyan, A. (2017). Gender inequality and growth in Europe. Intereconomics, 52(1), 17-23.

Knies, E., Leisink, P., \& Van De Schoot, R. (2020). People management: developing and testing a measurement scale. The International Journal of Human Resource Management, 31(6), 705-737.

KNOEMA (2019). World Data Atlas. Ukraine - Global gender gap index. Retrieved from https://knoema.com/atlas/Ukraine/topics/World-Rankings/World-Rankings/Global-gendergap-index on May 3, 2020.

Kokocinska, M., \& Puziak, M. (2018). Regional Income Differences and their Evolution after EU Accession. The Evidence from Visegrad Countries. Journal of Competitiveness, 10(4), 85-101.

Laundon, M., Cathcart, A., \& McDonald, P. (2019). Just benefits? Employee benefits and organisational justice. Employee Relations, 41(4), 708-723. https://doi.org/10.1108/ER-11-2017-0285

Mabaso, C.M., \& Dlamini, B.I. (2017). Impact of compensation and benefits on job satisfaction. Research Journal of Business Management, 11(2), 80-90.

Maloa, F., \&Bussin, M. (2016). Determinants of executive compensation in South African stateowned enterprises. South African Journal of Labour Relations, 40(1), 8-24. 
McKinsey (2015) Why diversity matters. Retrieved from https://www.mckinsey.com/business-functions/organization/our-insights/why-diversity-matters on April 20, 2020.

Mishchuk, H., Samoliuk, N., \& Bilan, Y. (2019). Measuring social justice in the light of effectiveness of public distributive policy. Administration \& Public Management Review, (32). 63-76. https://doi.org/10.24818/amp/2019.32-05

Novikova, O., \& Shamileva, L. (2020). Evaluation of social and economic insecurity risks for employees during structural transformations in the modern labor market. Social and Labour Relations: Theory and Practice, 10(1), 1-10.

Patiar, A., \& Wang, Y. (2020). Managers' leadership, compensation and benefits, and departments' performance: Evidence from upscale hotels in Australia. Journal of Hospitality and Tourism Management, 42, 29-39.

Plăiaş, I., Pop, C.M., Băbuţ, R., \& Dabija, D.C. (2011). Employers' Perception of Competences acquired through Academic Marketing Training. Amfiteatru Economic, 13(30), 448-463.

PwC (2017). Women in Work Index 2017. Retrieved from https://www.pwc.co.uk/services/economicspolicy/insights/women-in-work-index.html\#content-free-1-fadd on April 25, 2020.

Rasool, S.F., Samma, M., Wang, M., Zhao, Y., \& Zhang, Y. (2019). How Human Resource Management Practices Translate Into Sustainable Organizational Performance: The Mediating Role Of Product, Process And Knowledge Innovation. Psychology Research and Behavior Management, 12, 1009.

Šabić-Lipovača, A., Striełkowski, W., \& Bilan, Y., 2016. Intertemporal Substitution and Labour Supply of Bosnian SME's. Amfiteatru Economic, 18(43), 634-653.

Stacho, Z., Stachová, K., \& Raišienè, A.G. (2019). Change in approach to employee development in organizations on a regional scale. Journal of international Studies, 12(2), 299-308.

Stewart, G.L., \& Brown, K.G. (2019). Human Resource Management. John Wiley \& Sons.

Sułkowski, Ł., Bogacz-Wojtanowska, E., Wrona, S., Jędrzejczyk-Kozioł, A., Góral, E., \& Wojdyła, K. (2019). Unsustainable power distribution? Women Leaders in Polish Academia. Economics and Sociology, 12(3), 162-180. https://doi.org/10.14254/2071-789X.2019/12-3/11

Thibault Landry, A., Schweyer, A., \& Whillans, A. (2017). Winning the war for talent: Modern motivational methods for attracting and retaining employees. Compensation \& Benefits Review, 49(4), 230-246.

Turner, P. (2020). Why Is Employee Engagement Important? In Employee Engagement in Contemporary Organizations (pp. 57-84). Cham: Palgrave Macmillan.

UNDP. Sustainable Development Goals. Retrieved from http://www.undp.org/content/ undp/en/home/sustainable-development-goals.html_on April 28, 2020.

UNFPA Ukraine (2019). Gender Equality and Response to Domestic Violence in the Private Sector of Ukraine: Call for Action. Retrieved from https://ukraine.unfpa.org/en/BADV2019eng on April 25, 2020.

WEF (2018). Global Gender Gap Report 2018. Retrieved from https://www.weforum.org/reports/the-global-gender-gap-report-2018 on May 2, 2020.

WEF (2020). Global Gender Gap Report 2020. Retrieved from https://www.weforum.org/reports/gender-gap-2020-report-100-years-pay-equality on May 3, 2020.

Yu, S., Liu, C.E., \& Ren, H.Y.X.Y.J. (2019). Work-Related Identity Discrepancy and Employee Turnover Intention: The Mediation Effect of Job Satisfaction. International Journal of Business and Social Science, 10(11).

Zeb, A., Sultan, F., Hussain, K., Javaid, M., Abbas, Z., \& Imran, M. (2018). The influence of compensation and benefits and employees' involvement on employees' outcomes-evidence from PTCL. International Journal of Research and Review, 5(11), 98-103. 


\section{Authors}

Contribution share of authors is equal and amounted to $25 \%$ for each of them.

\section{Yuriy Bilan}

Associate professor, Alexander Dubcek University Trenčín, Slovakia; Al-Farabi Kazakh National University, Republic of Kazakhstan. His research interests include migration and labour market, sustainable development, energy and society.

Correspondence to: Prof. Yuriy Bilan, Dr hab., Rzeszów University of Technology, Faculty of Management, al. Powstańców Warszawy 12, 35-959 Rzeszów, Poland, e-mail: yuriy_bilan@yahoo.co.uk ORCID (1) http://orcid.org/0000-0003-0268-009X

\section{Halyna Mishchuk}

ScD. in Economics and Professor of Labour Resources and Entrepreneurship Department, National University of Water and Environmental Engineering (Ukraine). Her research interests include well-being, factors of migration and job satisfaction, social and economic equality.

Correspondence to: : Prof. Halyna Mishchuk, SCD, National University of Water and Environmental Engineering, Faculty of Economics and Management, Soborna str. 11, 33028 Rivne, Ukraine, e-mail: h.y.mischuk@nuwm.edu.ua

ORCID $\odot$ http://orcid.org/0000-0003-4520-3189

\section{Natalia Samoliuk}

PhD. in Economics and Associate Professor of Labour Resources and Entrepreneurship Department, National University of Water and Environmental Engineering (Ukraine). Her research interests include distributive justice, social dialogue and entrepreneurship.

Correspondence to: Prof. Natalia Samoliuk, PhD, National University of Water and Environmental Engineering, Faculty of Economics and Management, Soborna str. 11, 33028 Rivne, Ukraine, email:n.m.samoliuk@nuwm.edu.ua

ORCID (i) http://orcid.org/0000-0001-8693-8558

\section{Viktoriia Mishchuk}

Junior Research Fellow in the project "Formation of a comfortable environment for living and working for the achievement of social security in a transboundary space" funded by Ministry of Education and Science of Ukraine (state registration No. 0119U000080), National University of Water and Environmental Engineering (Ukraine). Her research interests include behavioural economics, personal skills, and competencies development.

Correspondence to: Viktoriia Mishchuk, National University of Water and Environmental Engineering, Soborna str. 11, 33028 Rivne, Ukraine, e-mail: mishchuk_em19@nuwm.edu.ua ORCID (1) https://orcid.org/0000-0003-3626-5652

\section{Copyright and License}

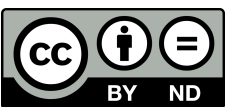

This article is published under the terms of the Creative Commons

Attribution - NoDerivs (CC BY-ND 4.0) License

http://creativecommons.org/licenses/by-nd/4.0/ 
The copyediting and proofreading of articles in English is financed in the framework Ministry of Science and Higher Education of contract No. 913/P-DUN/2019 by the Ministry of Science and Higher Education Repubic of foland of the Republic of Poland committed to activities aimed at science promotion. 